\title{
Estrogen and progesterone receptors in the peripheral giant cell granulomas of the oral cavity
}

\author{
Meral Günhan, Ömer Günhan ${ }^{\S}$ Bülent Celasun ${ }^{\S}$, Murat Mutlu and Hamit Bostanci
}

Department of Periodontalogy, Ankara University, School of Dentistry, Beşevler, and

Department of Pathology, Gülhane Military Medical Academy ${ }^{\S}$, Medical School, Etlik, Ankara

(Received 2 September 1997 and accepted 12 February 1998)

\begin{abstract}
Peripheral giant cell granulomas are common proliferative lesions of the oral cavity with a predilection for females. In this study, the presence of estrogen and progesterone receptors in 26 peripheral giant cell granuloma cases were studied utilizing the immunoperoxidase technique. In fourteen cases, estrogen receptor positivity was found in stromal cells. In ten of these, osteoclast-type giant cells also exhibited estrogen receptor immunostaining. Progesterone receptor expression was not detected. It was concluded that the cells forming peripheral giant cell granuloma are potential targets for estrogens and that these lesions might be conditioned by sex hormones. (J. Oral Sci. 40, 57-60, 1998)
\end{abstract}

Key words: giant cell granuloma; estrogen; progesterone; sex hormone receptors.

\section{Introduction}

Giant cell granuloma is a relatively common benign proliferative lesion of the oral cavity. It may arise peripherally or centrally. Peripheral lesions are more frequent and are encountered as localized nodular enlargements of the gingivae. These are sometimes called epulis. "Reparative giant cell granuloma" is an obsolete term for this lesion and implies a nonneoplastic proliferative biological nature. Antero-lateral tooth bearing mandibular segments are the most frequently involved areas.

The lesions are believed to arise from the periodontal ligament or mucoperiosteum. There is a controversy with respect to their histogenesis. Hormonal influences have been suggested as contributory factors in their development $(1,2)$ and predominance of these lesions in young females and some pregnancy related cases support this belief (1). Peripheral giant cell granulomas are also considered in a group of lesions called "pregnancy tumors" $(1,3)$. Since hormonally influenced lesions may contain cells with receptors for the related hormones, the present study aimed to investigate the presence and distribution of estrogen and progesterone receptors in peripheral giant cell granulomas. The possible roles of

Correspondence to Dr. Meral Günhan, Ankara Üniversitesi, Dişhekimliği Fakültesi, Periodontoloji ABD, Besevler Ankara, Turkey the female sex hormones on the histogenesis is also discussed.

\section{Materials and Methods}

Twenty-six gingival giant cell granulomas which had been totally excised and histologically examined between 1994 and 1996 constituted the material of the study. Of the patients, 15 were female and 11 were male. Ages ranged between 10 and 70 years. Eighteen of the lesions were in the mandible. Nineteen of the lesions were in the postero-lateral segments of the jaws.

Formalin-fixed ( 22 cases) or alcohol fixed ( 4 cases), paraffin-embedded tissue samples were retrieved from the files of the Department of Pathology. Four to six micron sections were prepared using poly-1-lysine coated slides. Since many of the tissues had been fixed in formalin, slides were placed in $\mathrm{Na}$ citrate buffer $0.01 \mathrm{M}$ (pH 6.0) for $10 \mathrm{~min}$. in a microwave oven (650 watts) to unmask the antigens. The containers were left to cool for $20 \mathrm{~min}$. Then, after washing the slides with distilled water, they were stained with monoclonal antibodies (Dako, Denmark) to detect estrogen (code no: M7047) and progesterone (code no: M3529) receptors. Decidual tissues, known to express significant amounts of estrogen receptors, were stained as positive controls. The primary antibodies were applied and refrigerated for $16 \mathrm{~h}$. Avidin-biotin peroxidase technique with TRIS buffer were used. The chromogen was aminoethyl carbazol (AEC). The sections were lightly counterstained with Mayer's hematoxylin.

The degree of immunopositive staining was assessed using a subjective index. This index was based on the density of nuclear and cytoplasmic staining for estrogen receptor, and nuclear staining only for progesterone receptors. The distribution of stained cells was also evaluated as diffuse or scattered staining. These were graded on a semiquantitative scale as follows: 0 : absent (no staining); 1: weak (slight scattered staining); 2: moderate (slight diffuse or prominent scattered staining); and, 3: strong (prominent diffuse staining).

\section{Histologic examination}

\section{Results}

The lesions were usually covered with acanthotic mucosa epithelium. In some cases there was superficial ulceration of the mucosa. The lesions revealed numerous 
unevenly distributed multinucleated giant cells in a cell rich stroma (Fig. 1). These giant cells accumulated especially around foci of hemorrhage and sinusoidal vascular structures. Stromal cells constituting the bulk of the lesions were plump or spindle shaped. Some lesions contained fine bone spicules.

\section{Immunohistochemical examination}

In fourteen cases, nuclear and cytoplasmic estrogen receptor immunostaining was seen on some stromal cells. Staining densities were weak to moderate. There was no strong staining. In twelve cases no estrogen receptor immunostaining was present. Alcohol fixed specimens showed better immunostaining.

In ten of the cases with stromal cell immunostaining, some osteoclast type giant cells also exhibited cytoplasmic estrogen receptor immunostaining (Fig. 2). Vascular structures (Figs. 2 and 3) and gingival mucosa epithelium showed weak positive cytoplasmic immunostaining for estrogen receptor antibodies in most of the cases. In four cases with intralesional bone tissue immunostaining for estrogen receptors were seen in the osteoid layer and osteoblasts. There were no cases where progesterone receptor immunostaining was detected in any part of the examined tissues. Control decidual tissues showed both strong nuclear and cytoplasmic estrogen and nuclear progesterone immunostaining. Table 1 summarizes the information on the cases and the results of immunostaining.

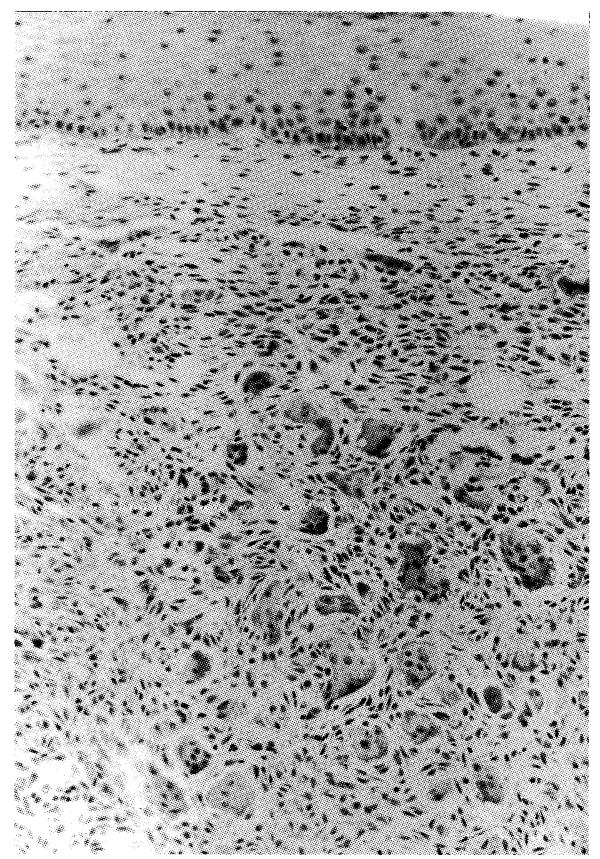

Fig. 1 Histopathologic appearance of a giant cell granuloma covered with oral epithelium. Note the presence of osteoclast type giant cells within the background of the proliferating stromal cells. $\times 100$.

\section{Discussion}

Gender is an important variable in the incidence of many diseases including some oral lesions. Hormonally sensitive lesions may express receptors for related hormones in their cells and an increased density of these may suggest strong hormonal influence (4-6). Receptors are also found in normal tissues $(4,6,7)$ and the presence of steroid receptors in the oral cavity including gingiva has been shown previously (6-8).

Steroid hormones including estrogen and progesterone are hydrophobic molecules that bind to intracellular receptor proteins localized within the cytoplasm and the nuclear membrane. These hormones regulate (activate or suppress) the transcription of specific genes depending on the metabolic condition of the cell (9).

Estrogen may stimulate the proliferation and maturation of gingival connective tissue and epithelium (7). It also provokes cancellous bone formation and is important for bone remodeling (10). Estrogen acts directly on osteoblasts and osteoclasts which bear estrogen receptors (11).

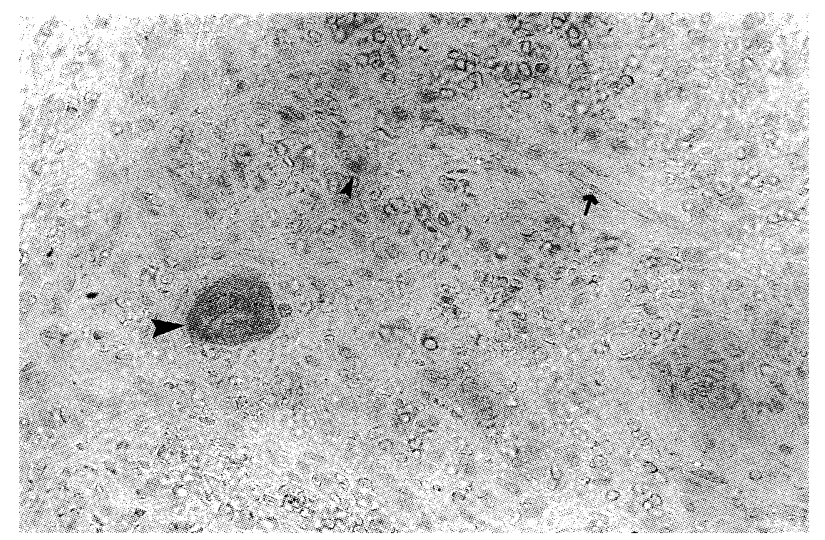

Fig. 2 Photomicrograph demonstrating the cytoplasmic and nuclear localization of estrogen receptor immunostaining in stromal cells (small arrow head), in giant cells (big arrow head) and in vascular endothelial cells (arrow). $\times 200$.

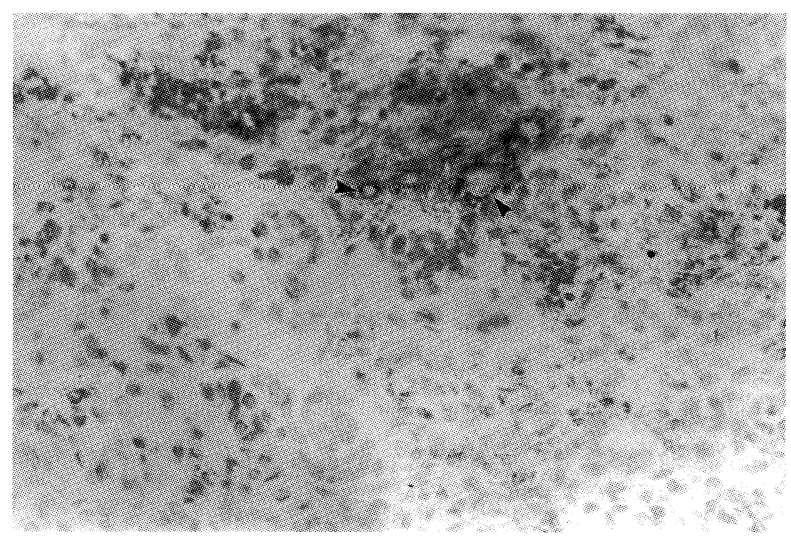

Fig. 3 One of the study cases lacking estrogen receptor expression on the stromal and giant cells. Note the positively stained vascular endothelial cells (arrow heads) serving as a positive internal control. $\times 200$. 
Table 1 Results of estrogen receptor immunostainings

\begin{tabular}{llcc}
\hline \multirow{3}{*}{ Age } & & Negative & Positive \\
& 15 & - & 3 \\
& $15-45$ & 7 & 9 \\
45 & 5 & 2 \\
\hline \multirow{4}{*}{ Site of staining } & Female & 4 & 11 \\
& Male & 8 & 3 \\
\hline & Mandible & 8 & 10 \\
& Maxillae & 4 & 4 \\
& Giant cells & 12 & 14 \\
& Oral epithelium* & 16 & 10 \\
& Vascular endothelium & 2 & 20 \\
& & 3 & 23 \\
\hline
\end{tabular}

* No covering epithelium was present in four of the cases.

Possible hormonal conditioning of peripheral giant cell granuloma has previously been suggested $(1,2,5)$. The predominance in females, the occasional association with pregnancy and the partial or complete regression after child birth suggest a female sex hormone influence (1).

The results of the present study suggest that at least some of the peripheral giant cell granuloma cases may be hormonally influenced. The predominance in females (15 female to 11 male) and the presence of estrogen receptor in 11 female versus 3 male patients support this notion. However, no significant difference was found between the degree of receptor expression in male and female subjects. None of the female patients were pregnant. Similar findings have been presented previously by Whitaker and Bouquot (5). They studied ten peripheral giant cell granuloma cases and estrogen receptor immunostaining was found in five cases; two of these were females. Our inability to demonstrate estrogen and progesterone receptors in every case might have been due to the low number of receptors. Flanagan et al. (12) suggested the hormonal stimulation on the growth of the peripheral giant cell granulomas were of secondary importance. According to these authors the main etiologic agent of giant cell granuloma was tooth-related chronic injury. In the present study, all lesions were found in the tooth-bearing jaw segments, lending some support to this theory. Mononuclear phagocytic system histiocytes have been suggested as the cells of origin of giant cell granulomas $(13,14)$. The stromal cells are the main component of the lesions. A large number of accompanying osteoclast type multinucleated cells give their name to the lesion. However, the factors inducing osteoclast recruitment and the functional significance of these cells are still poorly understood.

Giant cells were considered a phagocytic response to hemorrhage within the chronic reparative granulation tissue. However, giant cells do not contain hemosiderin in general and the lesion tends to grow progressively. The current consensus is that giant cell granulomas are not reparative in nature (12).

Osteoclastic activity in giant cell granuloma may be related to the exuberant stromal cell proliferation and bone remodeling. Estrogen receptors on the osteoclasts may modulate their resorptive functions (15). However, proliferation of osteoclasts in the lesion may be related to other factors since estrogen is also known to diminish the osteoclastic activity (15). There are fewer osteoclasts in small and early lesions.

Estrogen immunostaining on vascular endothelial cells was positive in the present cases. Increased levels of sex hormones may stimulate the vascular proliferation in areas of trauma $(16,17)$. Immunosuppressive effects of sex hormones on the inflammatory cells may provoke the development of pregnancy gingivitis and granuloma formation (17). Chronic irritations may be the initiating factor and estrogens may promote the occurrence of giant cell granulomas.

We believe that statements concerning the receptor densities and the pathogenesis of hormonally related lesions should be moderate. Immunohistochemical demonstration of hormone receptor expression is only a rough measure of hormone responsivity. The sensitivity, variety and tissue distribution of receptors are more important than their mere presence. On the other hand, therapeutic hormonal interventions can be successful only if there is sufficient information on the presence and tissue distribution of hormone receptors. Our study provides such information and the findings suggest that peripheral giant cell granuloma can indeed be hormone sensitive. It is not certain, however, whether this sensitivity is high enough to be manipulated for the benefit of the patient.

\section{References}

1. Caillouette, J. C. and Mattar, N. (1978) Massive peripheral giant-cell reparative granuloma of the jaw: a pregnancy dependent tumor. Am. J. Obstet. Gynecol. 131, 176-179

2. Flaggert, J. J., Heldt, L.V. and Gareis, F. J. (1987) Recurrent giant cell granuloma occurring in the mandible of a patient on high dose estrogen therapy for the treatment of Sotos' syndrome. J. Oral Maxillofac. Surg. 45, 1074-1076

3. Daley, T. D., Nartey, N. O. and Wysocki, G. P. (1991) Pregnancy tumor: an analysis. Oral Surg. Oral Med. Oral Pathol. 72, 196-199 
4. Molteni, A., Warpeha, R. L., Brizio-Molteni, L. and Fors, E. M. (1981) Estradiol receptor-binding protein in head and neck neoplastic and normal tissue. Arch. Surg. 116, 207- 210

5. Whitaker, S.B. and Bouquot, J. E. (1994) Identification and semi-quantification of estrogen and progesterone receptors in peripheral giant cell lesions of the jaws. J. Periodontol. 65, 280-283

6. Whitaker, S.B., Bouquot, J. E., Alimario, A. E. and Whitaker, T. J. Jr. (1994) Identification and semiquantification of estrogen and progesterone receptors in pyogenic granulomas of pregnancy. Oral Surg. Oral Med. Oral Pathol. 78, 755-760

7. Vittek, J., Hernandez, M. R., Wenk, E. J., Rappaport, S. C. and Southren, A. L. (1982) Specific estrogen receptors in human gingiva. J. Clin. Endocrinol. Metab. 54, 608- 612

8. Forabosco, A., Qriscuolo, M., Coukos, G., Uccelli, E., Weinstein, R., Spinato, S., Botticelli, A. and Volpe, A. (1992) Efficacy of hormone replacement therapy in postmenopausal women with oral discomfort. Oral Surg. Oral Med. Oral Pathol. 73, 570- 574

9. Alberts, B., Bray, D., Lewis, J., Raff, M., Roberts, K. and Watson, J. D. (1994) Molecular biology of the cell. Garland Publishing Inc, NewYork, 721-728

10. Gordan, G. S. (1985) Estrogen and bone. Marshall R. Uristís contributions. Clin. Orthop. 200, 174-180
11. Ohashi, T., Kusuhara, S. and Ishida, K. (1991) Immunoelectron microscopic demonstration of estrogen receptors in osteogenic cells of Japanese quaie. Histochemistry 96, 41-44

12. Flanagan, A. M., Nui, B., Tinkler, S. M., Horton, M. A., Williams, D. M. and Chambers, T. J. (1988) The multinucleate cells in giant cell granulomas of the jaws are osteoclasts. Cancer 62, 1139-1145

13. Regezi, J. A., Zarbo, R. J. and Lloyd, R. V. (1987) Muramidase, alpha-1 antitripsin, alpha-1 antichymotrypsin, and S-100 protein immunoreactivity in giant cell lesions. Cancer 59, 64-68

14. Carvalho, Y. R., Loyola, A. M., Gomez, R. S. and Araujo, V.C. (1995) Peripheral giant cell granuloma. An immunohistochemical and ultrastructural study. Oral Dis. 1, 20-25

15. Oursler, M. J., Osdoby, P., Pyfferoen, J., Riggs, B. L. and Spelsberg, T. C. (1991) Avian osteoclasts as estrogen target cells. Proc. Natl. Acad. Sci. USA 88, 6613-6617

16. Lindhe, J., Branemark, P. I. and Lundskog, J. (1967) Changes in vascular proliferation after local application of sex hormones. J. Periodontal Res. 2, 266-272

17. Ojanotko-Harri, A. O., Harri, M. P., Hurttia, H. M. and Sewön, L. A. (1991) Altered tissue metabolism of progesterone in pregnancy gingivitis and granuloma. J. Clin. Periodontol. 18, 262-266 